\title{
Challenges of COVID-19 and Tuberculosis - Urgent Need to Tackle the Dual Burden
}

\author{
Karma Gurmey Dolma1, Tooba Mahboob², Maria de Lourdes Pereira ${ }^{3}$, Christophe Wiart ${ }^{4}$, \\ Bidita Khandelwal ${ }^{5}$, Mohammed Rahmatullah ${ }^{6}$, Veeranoot Nissapatorn ${ }^{7}$
}

\begin{abstract}
${ }^{1}$ Department of Microbiology, Sikkim Manipal Institute of Medical Sciences, Sikkim Manipal University, Sikkim, India. ${ }^{2}$ Department of Medical Microbiology, University of Malaya, Kuala Lumpur, Malaysia. ${ }^{3}$ Department of Medical Sciences \& CICECO-Aveiro Institute of Materials, University of Aveiro, Averio, Portugal. ${ }^{4}$ University of Nottingham Malaysia Campus, Selangor, Malaysia ${ }^{5}$ Department of Medicine, Sikkim Manipal Institute of Medical Sciences, Sikkim Manipal University, Sikkim, India, ${ }^{6}$ Department of Biotechnology \& Genetic Engineering, University of Development Alternative Lalmatia, Dhaka, Bangladesh, ${ }^{7}$ Department of Allied Health Sciences, Southeast Asia Water Team (SEA Water Team), World Union for Herbal Drug Discovery (WUHeDD) and Research Excellence Centre for Innovation and Health Products (RECIHP), Walailak University, Nakhon Si Thammarat, Thailand.
\end{abstract}

\section{ABSTRACT}

The COVID-19 disease has currently overwhelmed all other health issues throughout the world. There can be many repercussions on existing public health issues, especially tuberculosis (TB), which is endemic in many low and middle-income countries (LMICs). In most of the LMICs, the health services are poorly equipped, the resources being diverted to control the pandemic of COVID-19, which can lead to grave consequences for LMICs. COVID-19 and TB are known to affect the respiratory system, so their symptoms are very similar, and at times can be perplexing for diagnosis.

Moreover, lack of proper treatment and vaccine for COVID-19 can further increase the mounting pressure. Synthetic drugs, such as hydroxychloroquine, are currently being used, but the side effects are a cause of concern. Hence, the efficacy of repositioned drugs is still under evaluation. The situation is further worsened by the possible development of drug-resistant mutants.

What we need in current times is potential novel anti-viral drugs that are highly productive and economic in control and management of viral infections in LMICs. The only option which we can look upon is the natural products which are also known as bioactive compounds and their phytochemicals like flavonoids, alkaloids and peptides that have anti-viral secondary metabolites which have shown promising results on COVID-19. This review systematically emphasizes the urgency for treatment options, which can be both safe and effective, especially for TB patients from LMICs.

\section{KEY WORDS}

Tuberculosis, COVID-19, Low and Middle Income Countries, Natural products, AntiViral Agents
Corresponding Author:

Dr. Karma Gurmey Dolma,

Ph. D. Associate Professor,

Department of Microbiology, Sikkim

Manipal Institute of Medical Sciences,

Sikkim Manipal University,

Sikkim, India.

E-mail:kgdolma@outlook.com

DOI: $10.14260 / \mathrm{jemds} / 2021 / 413$

How to Cite This Article:

Dolma KG, Mahboob T, De Lourdes Pereira $M$, et al. Challenges of Covid-19 and tuberculosis - urgent need to tackle the dual burden. I Evolution Med Dent Sci 2021;10(27):2018-2023, DOI: $10.14260 / \mathrm{jemds} / 2021 / 413$

Submission 05-02-2021, Peer Review 22-04-2021, Acceptance 28-04-2021, Published 05-07-2021.

Copyright ( 1021 Karma Gurmey Dolma et al. This is an open access article distributed under Creative Commons Attribution License [Attribution 4.0 International (CC BY 4.0)] 


\section{BACKGROUND}

The world initially came across COVID-19 when China first reported a cluster of respiratory diseases in the severe form of pneumonia on 31 ${ }^{\text {st }}$ December 2019, caused by SARS-CoV-2. ${ }^{1}$ This is the fifth coronavirus to affect humans since 2002, two others were discovered before 2002, making the total number as seven. Although the viruses have a high degree of genetic similarity, SARS-CoV-2 was considered more potent and on February 11 th 2020, World Health Organization (WHO) termed it as COVID-19 (for Corona Virus Induced Disease 2019). ${ }^{2}$ The COVID-19 has spread far and wide that the WHO declared it a pandemic on March $11^{\text {th }}, 2020$. This scenario with COVID-19 pandemic has been aggravating, for it has caused a global health crisis resulting in a huge impact on every part of the world. The intial reports of COVID-19 came around in early March in India unlike other countries, where it was detected much earlier, and hence there was a substantial delay in reporting the infection rates, disease burden, and fatal cases in India.

One of the most common and ancient disease affecting mankind and is a global public health problem even to this day is tuberculosis. ${ }^{3}$ Low-and middle-income countries (LMICs) are mainly affected by immense burdens of HIV, tuberculosis (TB) and malaria, and millions of people depend on these extensive programs to control and treat these infectious diseases. ${ }^{4}$ India alone is responsible for 625,000 of new cases and almost 100,000 of deaths annually ( $20 \%$ mortality rate), and as such leading the way. ${ }^{5}$ The scenario is deteriorated with the increasing number of drug resistant cases and mortality rates. Comprehensive reviews have highlighted that TB is still widely spread in many parts of the world, including India, and challenges caused by this pandemic have negatively impacted the prevention of TB surveillance and programs for treatment. ${ }^{6}$ Therefore, new strategies must be carried out to mitigate the public including widespread application of remote tele-consultations. The national program to combat TB needs to be vigorously engaged, warranting an operative and rapid response to COVID-19, while upholding TB services. The National Tuberculosis Elimination Program (NTEP) has made considerable progress, treating many patients over the years since its inception, but the rate of decline in TB incidence in India is not progressive enough to meet the goals set by NTEP for 2030. Hence, for TB elimination, the strategies have been incorporated into the four mainstays "Detect - Treat - Prevent - Build" (DTPB) ${ }^{7}$

Presently, in this situation, it is imperative to examine the possible effect the COVID-19 pandemic could have on a wellcontrolled TB program. With no proper medications, what we can see is a race against time to bring out a proper treatment for COVID-19. The antiviral drug, remdesivir and an antimalarial drug, chloroquine (CQ) / hydroxychloroquine (HCQ) have been used for COVID-19 treatment which have shown promising results in reducing the viral load in these patients ${ }^{8}$ However, these synthetic equivalents of quinine have been repurposed for treating many other diseases. Therefore, the lack of new drugs is a ticking time bomb for mankind as there could be possibilities of many new and reemerging infectious diseases in time to come. There is an exigent need to discover novel anti-microbial agents that are highly productive and economic for the management and control of various infections. For us the option left is what the nature has provided us with. Since, the beginning of mankind, plants have been the ultimate source of treatment for various diseases and modern medicine is primarily based on it. For millennia, the medically active constituents of natural products have had a pivotal role in treating many diseases over times. ${ }^{9}$ The immuno-stimulatory properties of plant extracts having anti-viral activities have been explored with the objective of boosting the intrinsic anti-viral defense of humans. Based on these previous studies, the objective of the present study was to provide an overview of the plants, which may be used for the treatment of SARS-CoV-2.

\section{Impacts and Challenges Observed}

The national TB programs have active surveillance, clinical assessment, testing and diagnosis and other resources in controlling the spread of TB, which have been seriously impacted by the emergence of COVID-19. The incidence of TB has had a different effect over the years, killing millions of people at different stages over time; including co-occurrence as the HIV epidemic in the 1980s, followed by the development of MDR / XDR TB and the emanation of several viral infection outbreaks in the world, which represented a major challenge for the global TB program. The pandemicity and its repercussion will be reflected over the coming years in various aspects of economy, trade infrastructure, food security and management of other infectious diseases. ${ }^{10}$ In most of the LMICs, the health services are poorly equipped, and the resources being diverted to control the spread of COVID-19 can have a grave consequence for the LMICs. With the everincreasing cases of COVID-19 all over the world, many measures were initiated to lessen the transmission risk, and hospitals were forced to minimize the outpatient visits. ${ }^{11}$ Most hospitals across the country had to set-up a designated COVID19 area and priority was focused on the emergency setting up of testing centres and quarantine centers. ${ }^{12}$ To break the chain of transmission, the government had announced several measures to decrease the probable exposure of infection, like closing schools, libraries and other public spaces; enhanced disinfection in public spaces; and recommending a 14-day home quarantine for individuals in epidemic areas. ${ }^{11}$ Interstate as well as inter-district movements were also cut down drastically and the residents were requested to stay at home unless there was an emergency. ${ }^{13}$

The changes introduced to restrain the spread of COVID19 have caused many problems to the general public particularly to the patients with TB symptoms who seek healthcare and were unable to go to hospitals due to movement restrictions or due to the fear of the virus. This resulted in a major barrier for patients, leading to further delays in diagnosis of fresh cases of TB. The interventions introduced to curb the spread could result in severe limitations in the availability of health services and in the access for the diagnosis and management of TB cases, ${ }^{14}$ but on the other hand, the practice of social distancing in public could help immensely in reducing the transmission of TB. ${ }^{15}$ As tuberculosis is an air-borne disease, it is known that the poor indoor ventilation system further helps in the spread of the disease, especially among the household contacts, where in 
this current situation, suspected cases are forced to spend more time indoors.

There are many pre-disposing factors which are similar between the two diseases that thrive on their prevalence like over crowding, close contact and many other socioeconomic and epidemiological factors. ${ }^{16}$ Although the measure can be seen as a good effort to curb the transmission of the community spread of COVID-19, nevertheless, what we can also expect in the coming days is a spike in the number of TB cases, due to household transmission of TB among close contacts. ${ }^{17}$ Hogan et al. ${ }^{18}$ modelled a study to quantify the extent of disruptions in TB program services in low- and middle-income countries due to COVID-19 where in highly endemic countries, an increase of $20 \%$ in TB related deaths is foreseen over the next 5 years.

A major concern is the interruption of treatment not only for positive tuberculosis patients, but also for the multidrugresistant TB (MDR-TB), as patients should attend at regular intervals for follow-up examination and treatment. With the spread of the pandemic, there was a dramatic decrease in the detection of new cases of TB, not only in India, but also in other countries. ${ }^{6}$

There was a considerable decrease in the detection of new TB cases, as seen on the Central TB Nikshay portal of Government of India. There was a decrease of $78 \%$ from April $2019(1,56,000$ cases $)$ to April $2020(34,342) .{ }^{19}$ The possibility of co-existence of SARS-CoV-2 and Mycobacterium tuberculosis (TB) in the present pandemic is imminent. ${ }^{20}$

As there are similarities in the clinical presentation of the symptoms of COVID-19 and TB, what we can expect is not only the imperative loss of the patient's health, but such situation can also affect the economic status of a patient directly or indirectly. COVID-19 and TB affect the respiratory system, and hence their symptoms are very similar, at times can be confusing for diagnosis.

Moreover, the lack of proper treatment and drug resistant cases can have a lasting impact of the overbearing cost of the disease, stigmatization, and the chances of spread to the family members, the community as well as to the navigation of the programs.

Predisposition of COVID-19 infection to a TB patient and Covid patient to tuberculosis infection can be concurrent as both these infections affect mainly the respiratory system and can have poor prognosis in both the cases.21 Presently, the main mode of treatment is supportive treatment, while further complications may require ventilation assistance. ${ }^{22}$ Few experimental studies have found the use in combination therapy of lopinavir, remdesivir, lamivudine and tenofovir etc. for therapeutic use against COVID-19.23 Numerous vaccines are under pre-clinical trials approved by the WHO and two vaccines manufactured by Pfizer-BioNTech and Moderna have been permitted by the US Food and Drug Administration for vaccinating the population. Many scientists are undertaking great measures to develop an effective vaccine in a bid to save time, ${ }^{24}$ but the main drawbacks of these vaccines could be that in the absence of animal studies the outcome or effect of the vaccines cannot be foretold in humans. ${ }^{25}$ One of the major public health strategies that we need to focus is on the development of effective treatment which should be cost-effective and immune enhancing treatment. We need to look into other options and strategies where the virus can be eliminated, and the cost of the medication does not affect the LMICs countries. Hence, all these factors need to be reconsidered as a major public health priority.

\section{TREATMENT STRATEGIES AND FUTURE PERSPECTIVES}

The WHO report states that $80 \%$ of people from the developing nations have benefitted from the usage of traditional plants for health and vitality. ${ }^{26}$ There have been numerous studies that have proven that plant products and their preparations have been effective against many viral outbreaks. ${ }^{27}$

The plant extracts and their secondary metabolites from various parts of a plant have been found to work against both the infectious as well as non-infectious ailments. ${ }^{28}$ Moreover, their low toxicity is an added advantage ${ }^{29}$ and hence, can be comprehensively used to target COVID-19.30,31 Natural products have been established as important components of healing progress in almost all aspects of human health. ${ }^{32}$ The secondary metabolites of the natural products and their analogues derived from these structures are indispensable in the field of drug development. ${ }^{32}$ In the clinical therapies for TB, the two main drugs isoniazid and rifampin are known derived natural products of nicotinamide and rifamycin respectively. However, in spite of its successful discovery in 1960, there has been no new structural classes of anti-tubercular antibiotics. ${ }^{33}$ The infectious characteristics of both TB and COVID-19 can make the way for the development of new drugs or even vaccines. For example, the potential to develop plant-based vaccines against COVID-19 was highlighted by S RosalesMendoza and co-workers. ${ }^{34}$

In the pandemic spread of COVID-19, exploration and development of a perfect treatment is very essential and based on the surveillance, many pursuits are being carried out to identify medicinal plants with antiviral activities. These plants should also possess many important features like RNA viral inhibition, ACE2 inhibitor, immuno-modulator, chloroquine derivatives, among others. A development of such methodologies can create opportunities for medicinal plant usage in the discovery of modern drugs. The treatment module recommended by regulatory bodies suggest the usage of chloroquine, antiviral drugs, vitamin C, zinc supplement, ACE2 inhibitors, RNA viral inhibitors, and plasma therapy. ${ }^{35}$ There have been many studies that have demonstrated the inhibitory effects of the natural products on several viruses. In particular, studies on HSV-2,36 HIV, ${ }^{37} \mathrm{HBV},{ }^{38}$ and even SARS 39 have demonstrated the effects of various plant extracts on these viruses. The Traditional Chinese Medicine (TCM) is known for its remarkable wealth of ancient knowledge on medicinal plants and its prominence was evident in emerging pandemics when it's effect was amalgamated with allopathic medicine in the administration of the SARS outbreak in 2003.40

Further, its usage was meticulously planned into the COVID-19 treatment guidelines ${ }^{41}$ by the National Health Commission of the People's Republic of China. The representation of the symptoms of COVID-19 and TB is the lungs, since both diseases are essentially affecting the lungs, 
the probability of treating both diseases with the same plant and their bioactive constituents can help in making the treatment affordable and easily accessible for the LMICs. Also, the side effects of these natural products are limited as compared to other synthetic drugs. Some of these natural products have powerful antivirals that block certain viruses from replicating in the body.

\begin{tabular}{|c|c|c|c|c|}
\hline S.No. & Name of the Plant & Major Active Constituents & Therapeutic Use & References \\
\hline 1 & $\begin{array}{c}\text { Black elderberry (Sambucus nigra } \\
\text { L.) }\end{array}$ & $\begin{array}{l}\text { Anthocyanins cyaniding 3-glucoside. cyanidin 3- } \\
\text { sambubioside. carotenoids, phytosterols and } \\
\text { polyphenols }\end{array}$ & Influenza, Cold and sinusitis & Evelin tiralongo.et al. ${ }^{42}$ \\
\hline 2 & Garlic (Allium sativum L.) & Ajoene, Allicin, Diallylsulphides, vinyldithiins (VD) & $\begin{array}{l}\text { Antimicrobial, anti-cancer, antioxidant, } \\
\text { immunomodulatory, anti-inflammatory, } \\
\text { hypoglycaemic, and anticardiovascular effects }\end{array}$ & Swapna S. Nair. et al.43 \\
\hline 3 & $\begin{array}{l}\text { Giloya (Tinospora cordifolia } \\
\text { (Willd.) Miers }\end{array}$ & Terpenoids, flavonoids & $\begin{array}{l}\text { Antioxidant, hepatoprotective, anticancer, } \\
\text { antiallergic, immunomodulatory, and anti- } \\
\text { inflammatory effects }\end{array}$ & P. R. Polu. et al. ${ }^{44}$ \\
\hline 4 & $\begin{array}{l}\text { Galangal (Alpinia galanga (L.) } \\
\text { Willd. }\end{array}$ & Terpenoids, flavonoids, Phenolics & $\begin{array}{c}\text { Kidney disorders, diabetes, cough, tuberculosis, } \\
\text { bronchitis, rheumatism, asthma, and heart } \\
\text { diseases. }\end{array}$ & H. N. Jnawali. et al. ${ }^{45}$ \\
\hline 5 & Tulsi, (Ocimum sanctum L.) & $\begin{array}{c}\text { Rosmarinic acid, linalool, methylchavicol, } \\
\text { methylcinnamat, 1,7 -dimethyl, 6-octadien-3-ol, } \\
\text { and eugenol }\end{array}$ & $\begin{array}{l}\text { Heart problems, Asthma, bronchitis, eye } \\
\text { disorders, arthritis }\end{array}$ & Sai Krishna. G. et al. ${ }^{46}$ \\
\hline 6 & $\begin{array}{l}\text { Margosa (Azadirachta indica } \\
\text { A.Juss) }\end{array}$ & $\begin{array}{l}\text { Neem nimbidin, sodium nimbidate, Gallic acid, } \\
\text { catechin, polysaccharides, gedunin, cyclic trisulfide, } \\
\text { nimbolide, mahmoodin, margolone, margolonone, } \\
\text { isomargolonone }\end{array}$ & $\begin{array}{l}\text { Pertussis and cough up blood, GNB, GPC, anti- } \\
\text { ulcer, anti-fungal, anti-carcinogenic }\end{array}$ & Cut Fatimah. et al. ${ }^{47}$ \\
\hline 7 & Ginseng, (Panax quinquefolius L.) & $\begin{array}{l}\text { Triterpenoid, protopanaxadiols, protopanaxatriols } \\
\text { and steroidal saponins }\end{array}$ & $\begin{array}{l}\text { Antimicrobial, antioxidative, antidiabetic, anti- } \\
\text { inflammatory, anticardiovascular disease and } \\
\text { anticancer properties. }\end{array}$ & Won Sriwijitalai. et al. ${ }^{48}$ \\
\hline 8 & $\begin{array}{l}\text { Aswagandha, (Withania somnifera } \\
\text { (L.) Dunal }\end{array}$ & $\begin{array}{l}\text { Triterpene lactones-withanolides, withaferin A \& D, } \\
\text { steroidal lactones, alkaloids, Tropine and } \\
\text { Cuscohygrine }\end{array}$ & $\begin{array}{l}\text { Ulcers, fever, cough, dyspnoea, consumption } \\
\text { dropsy, impotence, rheumatism, toxicosis and } \\
\text { leukoderma }\end{array}$ & Ranjeet Kumar. et al. ${ }^{49}$ \\
\hline 9 & $\begin{array}{l}\text { Astragalus membranaceus Fisch. } \\
\text { Ex Bunge }\end{array}$ & $\begin{array}{c}\text { Polysaccharides, flavonoids, and triterpene } \\
\text { saponins }\end{array}$ & $\begin{array}{c}\text { Inflammatory diseases and cancers and anti- } \\
\text { viral }\end{array}$ & Yuan et al..$^{50}$ \\
\hline 10 & Lonicera japonica Thunb. & $\begin{array}{c}\text { Chlorogenic acid, flavonoid, caffeoylquinic acid, and } \\
\text { iridoid glycoside }\end{array}$ & $\begin{array}{l}\text { Anti-viral, anti-bacterial and anti-inflammatory } \\
\text { activities. }\end{array}$ & Li Y et al. ${ }^{51}$ \\
\hline 11 & Dendrobium nobile Lindl. & $\begin{array}{l}\text { Vitamin A Aldehyde; Longifolene; 1- } \\
\text { Heptatriacotanol; Z, Z-6, 28-Heptatriactontadien-2- } \\
\text { One and Dendroban-12-One. }\end{array}$ & $\begin{array}{l}\text { Curing eye infection, anti-ageing, antimicrobial, } \\
\text { aphrodisiac, fever, stomachic, tongue dryness } \\
\text { and analgesic, pulmonary tuberculosis }\end{array}$ & Sarsaiya et al..$^{52}$ \\
\hline 12 & Atractylodis rhizoma & $\begin{array}{l}\text { Codonolactone, a sesquiterpene lactone, Hinesol, } \\
\text { Atractylenolide }\end{array}$ & $\begin{array}{l}\text { Treating fever, cold, phlegm, edema and } \\
\text { arthralgia syndrome antiviral (Influenza A } \\
\text { virus), anti-inflammatory, antibacterial, and } \\
\text { anti-allergic, gastro-protective, anticancer and } \\
\text { neuro protective activities. }\end{array}$ & Cheng Y et al..$^{53}$ \\
\hline 13 & $\begin{array}{l}\text { Glycyrrhiza uralensis Fisch., } \\
\text { Glycyrrhiza inflata Bat., } \\
\text { Glycyrrhiza glabra L. }\end{array}$ & $\begin{array}{l}\text { Triterpene saponins, glycyrrhizin, glycyrrhizic acid, } \\
\text { flavanones, chalcones, triterpenoid saponins, } \\
\text { coumarines, and other glycosides. }\end{array}$ & $\begin{array}{c}\text { Coughs and Influenza, and for detoxification, } \\
\text { Anti-ulcer action, anticancer action, anti- } \\
\text { allergic and anti-inflammatory effects, anti- } \\
\text { virus and antibacterial activities, and effect on } \\
\text { immune function }\end{array}$ & Nazari et al. ${ }^{54}$ \\
\hline 14 & $\begin{array}{l}\text { Anemarrhena asphodeloides } \\
\text { Bunge. }\end{array}$ & $\begin{array}{c}\text { Steroidal saponins, flavonoids, phenylpropanoids, } \\
\text { alkaloids, steroids, organic acids, anthraquinones, } \\
\text { and others. }\end{array}$ & $\begin{array}{l}\text { Cold-induced febrile disease with arthralgia } \\
\text { tidal fever, bone-steaming, cough, and } \\
\text { haemoptysis }\end{array}$ & Wang Y et al. ${ }^{55}$ \\
\hline 15 & $\begin{array}{l}\text { Coptis chinensis Franch., } C \text {. } \\
\text { deltoidea C.Y. Cheng et Hsiao, or } C \text {. } \\
\text { Teeta Wall }\end{array}$ & $\begin{array}{l}\text { Alkaloids, organic acids, coumarins, } \\
\text { phenylpropanoids, Berberine quinones, }\end{array}$ & $\begin{array}{l}\text { Bacillary dysentery, diabetes, pertussis, sore } \\
\text { throat and eczema }\end{array}$ & Wang J et al. ${ }^{56}$ \\
\hline 16 & Cassia sophora Collad. & $\begin{array}{l}\text { Alkaloids, Saponins, Flavonoids, Tannins, } \\
\text { Anthraquinones, Cardiac glycosides }\end{array}$ & $\begin{array}{l}\text { Psoriasis, cough, arthritis, diabetes and } \\
\text { convulsions, ringworm, hepatoprotective } \\
\text { activity. }\end{array}$ & Ahmad B et al. ${ }^{57}$ \\
\hline 17 & Urtica dioica $\mathrm{L}$. & Tannins, Terpenoids, Anthraquinones & $\begin{array}{l}\text { Antioxidant, antimicrobial, antiulcer and } \\
\text { analgesic activities }\end{array}$ & Gülçin I et al..$^{58}$ \\
\hline 18 & Tribulus terrestris $\mathrm{L}$. & Alkaloids, Saponins, Tannins & $\begin{array}{l}\text { Tonic, aphrodisiac, analgesic, astringent, } \\
\text { stomachic, antihypertensive, diuretic and } \\
\text { lithontriptic and also for the treatment of } \\
\text { urinary tract infections }\end{array}$ & Adaikan PG et al. ${ }^{59}$ \\
\hline 19 & $\begin{array}{l}\text { Beilschmiedia obscura (Stapf.) A. } \\
\text { Chev. }\end{array}$ & $\begin{array}{l}\text { Phenols, Sterols, Tannins, Flavonoids, Lipids, } \\
\text { Glycosides }\end{array}$ & $\begin{array}{l}\text { Active against Gram negative bacteria, } \\
\text { respiratory problems }\end{array}$ & G. Fankam et al. ${ }^{60}$ \\
\hline 20 & $\begin{array}{c}\text { Acanthus montanus (Nees) T. } \\
\text { Anderson }\end{array}$ & $\begin{array}{l}\text { Sterols,Tannins, Flavonoids, Lipids, Glycosides, } \\
\text { Sugars }\end{array}$ & $\begin{array}{l}\text { Active against Gram negative bacteria, Fever, } \\
\text { furuncles, cancer, ulcer, cough }\end{array}$ & Ikezu et al. ${ }^{61}$ \\
\hline \multicolumn{5}{|c|}{ Table 2. Natural Products for COVID-19 and TB Treatment } \\
\hline
\end{tabular}

\section{CONCLUSIONS}

Overall, the forthcoming challenge that we face from the possible effect of COVID-19 on TB is anticipated. The national TB programs need to have an active surveillance, clinical assessment, testing and diagnosis and other resources in great order for controlling the spread of TB. Strong efforts need to be directed to contain the spread of these deadly diseases as both affect the respiratory system.

There is an exigent need to discover novel anti-microbial agents that are highly productive and economic for the management and control of these type of infections. Plants have a lot to offer for treating these infectious diseases. Though, the challenge we face is that there is still a long way to go for further validation of these natural products to be used as some anti-viral agents.

Therefore, the use of alternative medicine should be brought out on a bigger platform and it could lead to development of a novel drug / molecule which would be beneficial and planned against these two diseases in order to prepare for future challenges.

Financial or other competing interests: None.

Disclosure forms provided by the authors are available with the full text of this article at jemds.com. 


\section{REFERENCES}

[1] Lu R, Zhao X, Li J, et al. Genomic characterisation and epidemiology of 2019 novel coronavirus: implications for virus origins and receptor binding. Lancet 2020;395(10224):565-74.

[2] Chopra KK, Arora VK, Singh S. COVID 19 and tuberculosis. Indian J Tuberc 2020;67(2):149-51.

[3] Kyu HH, Maddison ER, Henry NJ, et al. The global burden of tuberculosis: results from the global burden of disease study 2015. Lancet Infect Dis 2018;18(3):261-84.

[4] Walker PGT, Whittaker C, Watson OJ, et al. The impact of COVID-19 and strategies for mitigation and suppression in low-and middle-income countries. Science 2020;369(6502):413-22.

[5] WHO. Global tuberculosis report 2019. WHO/CDS/TB/2019.15 https://www.who.int/tb/publications/global_report/e/

[6] Jain VK, Iyengar KP, Samy DA, et al. Tuberculosis in the era of COVID-19 in India. Diabetes Metab Syndr 2020;14(5):1439-43.

[7] Annual Status Report. Central TB division, directorate general of health services. India TB Report. New Delhi: India Offset Press 2018.

[8] Gautret P, Lagier JC, Parola P, et al. Hydroxychloroquine and azithromycin as a treatment of COVID-19: results of an open-label non-randomized clinical trial. Int J Antimicrob Agents 2020;56(1):105949.

[9] Webster D, Taschereau P, Lee TDG, et al. Immunostimulant properties of heracleum maximum bartr. J Ethnopharmacol 2006;106(3):360-3.

[10] Bandyopadhyay A, Palepu S, Bandyopadhyay K, et al. COVID-19 and tuberculosis co-infection: a neglected paradigm. Monaldi Arch Chest Dis 2020;90(3).

[11] Pang Y, Liu Y, Du J, et al. Impact of COVID-19 on tuberculosis control in China. Int J Tuberc Lung Dis 2020;24(5):545-7.

[12] The Lancet. India under COVID-19 lockdown. Lancet 2020;395(10233):1315.

[13] Chen S, Yang J, Yang, W, et al. COVID-19 control in China during mass population movements at new year. Lancet 2020;395(10226):764-6.

[14] Ministry of Family and Welfare. Government of India. Public Information Bureau. https://pib.gov.in/ PressReleasePage.aspx?PRID $1 / 41606079$. [Accessed 24 June 2020].

[15] World Health Organisation. Tuberculosis and COVID-19. https://www.who.int/docs/defaultsource/documents/tuberculosis/infonote-tb-COVID19.pdf. [Accessed 11 May 2020].

[16] Khurana AK, Aggarwal D. The (in)significance of TB and COVID-19 co-infection. Eur Respir J 2020;56(2):2002105.

[17] Alene KA, Wangdi K, Clements ACA. Impact of the COVID19 pandemic on tuberculosis control: an overview. Trop Med Infect Dis 2020;5(3):123.

[18] Hogan AB, Jewell BL, Sherrard-Smith E, et al. Potential impact of the COVID-19 pandemic on HIV, tuberculosis and malaria in low-income and middle-income countries: a modelling study. Lancet Glob Health 2020;8(9):e113241.
[19] Government of India. Central Tuberculosis Division. India TB report 2020. https://tbcindia.gov.in/. [Accessed 10 July 2020].

[20] He G, Wu J, Shi J, et al. COVID-19 in tuberculosis patients: a report of three cases. J Med Virol 2020;92(10):1802-6.

[21] World Health Organisation. Information Note: COVID-19: considerations for tuberculosis (TB) care. Rev Ed 2020. [cited $10 \quad$ May 2020]. https://www.who.int/tb/COVID_19considerations_tube rculosis_services.pdf.

[22] COVID-19 India. https://www.mohfw.gov. [Accessed 10 July 2020]. Accessed on.

[23] Lu H. Drug treatment options for the 2019-new corona virus (2019-nCoV). Biosci Trends 2020;14(1):69-71.

[24] Calina D, Docea AO, Petrakis D, et al. Towards effective COVID 19 vaccines: updates, perspectives and challenges (Review). International Journal of Molecular Medicine 2020;46(1):3-16.

[25] Gralinski LE, Menachery VD. Return of the coronavirus: 2019-nCoV. Viruses 2020;12(2):135.

[26] Medicinal plants and primary health care: part 2. Essent Drugs Monit 1991;11:15-7.

[27] Ganjhu RK, Mudgal PP, Maity H, et al. Herbal plants and plant preparations as remedial approach for viral diseases. Virus disease 2015;26(4):225-36.

[28] Katona P, Katona-Apte J. The interaction between nutrition and infection. Clin Infect Dis 2008;45(10):15828.

[29] Zhang J, Onakpoya IJ, Posadzki P, et al. The safety of herbal medicine: from prejudice to evidence. Evid Based Complement Alternat Med 2015;2015:316706.

[30] Bhuiyan FR, Howlader S, Raihan T, et al. Plants metabolites: possibility of natural therapeutics against the COVID-19 pandemic. Front Med (Lausanne) 2020;7:444.

[31] Benarba B, Pandiella A. Medicinal plants as sources of active molecules against COVID-19. Front Pharmacol 2020;11:1189.

[32] Newman DJ, Cragg GM. Natural products as sources of new drugs over the last 25 years. J Nat Prod 2007;70(3):461-77.

[33] Maggi N, Pasqualucci CR, Ballotta R, et al. A new orally active rifamycin. Chemotherapy 1966;11(5):285-92.

[34] Rosales-Mendoza S, Márquez-Escobar VA, GonzálezOrtega 0 , et al. What does plant-based vaccine technology offer to the fight against COVID-19? Vaccines (Basel) 2020;8(2):183.

[35] Cascella M, Rajnik M, Cuomo A, et al. Features, evaluation and treatment coronavirus (COVID-19). In: StatPearls. Treasure Island (FL): StatPearls Publishing 2020.

[36] Debiaggi M, Pagani L, Cereda PM, et al. Antiviral activity of Chamaecyparis lawsoniana extract: study with herpes simplex virus type 2. Microbiologica 1988;11(1):55-61.

[37] Asres K, Bucar F. Anti-HIV activity against immunodeficiency virus type 1 (HIV-I) and type II (HIVII) of compounds isolated from the stem bark of combretum molle. Ethiop Med J 2005;43(1):15-20.

[38] Huang KL, Lai YK, Lin CC, et al. Inhibition of hepatitis B virus production by Boehmeria nivea root extract in HepG2 2.2.15 cells. World J Gastroenterol 2006;12(35):5721-5. 
[39] Kotwal GJ, Kaczmarek JN, Leivers S, et al. Anti-HIV, antipoxvirus and anti-SARS activity of a nontoxic, acidic plant extract from the Trifollium species Secomet-V/anti-vac suggests that it contains a novel broad-spectrum antiviral. Ann N Y Acad Sci 2005;1056(1):293-302.

[40] Chen Z, Nakamura T. Statistical evidence for the usefulness of Chinese medicine in the treatment of SARS. Phytother Res 2004;18(7):592-4.

[41] Sahu KK, Mishra AK, Lal A. Comprehensive update on current outbreak of novel coronavirus infection (2019nCoV). Ann Transl Med 2020;8(6):393.

[42] Tiralongo E, Wee SS, Lea RA. Elderberry supplementation reduces cold duration and symptoms in air-travellers: a randomized, double-blind placebo-controlled clinical trial. Nutrients 2016;8(4):182.

[43] Nair SS, Gaikwad SS, Kulkarni SP, et al. Allium sativum constituents exhibit anti-tubercular activity in-vitro and in RAW 264.7 mouse macrophage cells infected with mycobacterium tuberculosis H37Rv. Pharmacogn Mag 2017;13(Suppl 2):S209-15.

[44] Polu PR, Nayanbhirama U, Khan S, et al. Assessment of free radical scavenging and anti-proliferative activities of Tinospora cordifolia miers (Willd). BMC Complement Altern Med 2017;17(1):457.

[45] Jnawali HN, Jeon D, Jeong MC, et al. Antituberculosis activity of a naturally occurring flavonoid, isorhamnetin. J Nat Prod 2016;79(4):961-9.

[46] Krishna GS, Ramesh TB, Kumar PP. Tulsi-the wonder herb (Pharmacological Activities of Ocimum Sanctum). American Journal of Ethnomedicine 2014;1(1):89-95.

[47] Fatimah C, Wahyudi E, Ernawati B. Antituberculosis and toxicity assay of ethanolic extract of mimba cortex (Azadirachta indica JUSS.) Indonesian Journal of Cancer Chemoprevention 2015;6(2):49-52.

[48] Sriwijitalai W, Wiwanitkit V. Effect of ginseng against tuberculosis: a pathway interrelationship analysis. Biomed Biotechnol Res J 2019;3(2):120-5.

[49] Kumar R, Rai J, Kajal NC, et al. Comparative study of effect of Withania somnifera as an adjuvant to DOTS in patients of newly diagnosed sputum smear positive pulmonary tuberculosis. Indian J Tuberc 2018;65(3):246-51.

[50] Yuan WL, Chen HZ, Yang YZ, et al. Effect of astragalus membranaceus on electric activities of cultured rat beating heart cells infected with Coxsackie B-2 virus. Chin Med J 1990;103(3):177-82.

[51] Li Y, Li W, Fu C, et al. Lonicerae japonicae flos and Lonicerae flos: a systematic review of ethnopharmacology, phytochemistry and pharmacology. Phytochem Rev 2019:1-61.

[52] Sarsaiya S, Jain A, Fan X, et al. New insights into detection of a dendrobine compound from a novel endophytic Trichoderma longibrachiatum strain and its toxicity against phytopathogenic bacteria. Front Microbiol 2020;11:337.

[53] Cheng Y, Mai JY, Hou TL, et al. Antiviral activities of atractylon from Atractylodis rhizoma. Mol Med Rep 2016;14(4):3704-10.

[54] Nazari S, Rameshrad M, Hosseinzadeh H. Toxicological effects of Glycyrrhiza glabra (licorice): a review. Phytother Res 2017;31(11):1635-50.

[55] Wang Y, Dan Y, Yang D, et al. The genus Anemarrhena bunge: a review on ethnopharmacology, phytochemistry and pharmacology. J Ethnopharmacol 2014;153(1):4260.

[56] Wang J, Wang L, Lou GH, et al. Coptidis rhizoma: a comprehensive review of its traditional uses, botany, phytochemistry, pharmacology and toxicology. Pharm Biol 2019;57(1):193-225.

[57] Ahmad B, Khan NA, Ahmad G, et al. Hepatoprotective effect of seeds of Cassia sophera, linn. Var. Purpurea, roxb. against $\mathrm{CCl}_{4}$ induced hepatic damage in albino rats. Pharmacogn Mag 2005;1(2):68-70.

[58] Gülçin I, Küfrevioglu ÖI, Oktay M, et al. Antioxidant, antimicrobial, antiulcer and analgesic activities of nettle (Urtica dioica). J Ethnopharmacol 2004;90(2-3):205-15.

[59] Adaikan PG, Gauthaman K, Prasad RNV. History of herbal medicines with insight on the pharmacological properties of Tribulus terrestris. The Aging Male 2001;4(3):163-9.

[60] Fankam G, Kuiate JR, Kuete V. Antibacterial activities of Beilschmiedia obscura and six other Cameroonian medicinal plants against multi-drug resistant Gramnegative phenotypes. BMC Complementary and Alternative Medicine 2014;14:1.

[61] Ikezu UJM, Ajiwe VIE, Ilozue NM, et al. Structural elucidation and antimicrobial analysis of chloroform leaf extract of Acanthus montanus. Journal of Applied Chemistry 2014;7(6):72-5. 